\title{
Commentary: Come in from the cold
}

Abe DeAnda, Jr, MD, ${ }^{a}$ and Sean G. Yates, $\mathrm{MD}^{\mathrm{b}}$

Perioperative bleeding is a recognized complication of cardiac procedures, with increased risks associated with cases performed on cardiopulmonary bypass and those requiring hypothermia. This complication is further compounded by evidence demonstrating that blood transfusions negatively impact both short- and long-term morbidity and mortality. ${ }^{1-4}$

Sultan and colleagues ${ }^{5}$ have reported their institution's experience with blood product use in aortic surgery and resultant postoperative outcomes. Although this study is not the first to evaluate this issue, it is one of the largest to date, with the authors assessing 824 patients undergoing aortic surgery requiring circulatory arrest and comparing propensity-matched cohorts separated based on the need for transfusion. Ultimately, the authors found that longer procedure times and greater surgical complexity corresponded with increased blood component transfusions, with greater mortality rates demonstrated in those receiving transfusions. Although it is generally accepted that aortic procedures associated with deep hypothermic circulatory arrest (DHCA) often use more blood products, Sultan and colleagues suggest that DHCA coupled with blood component transfusion results in significantly worse outcomes.

The hemostatic system functions optimally at normothermia (ie, $\sim 37^{\circ} \mathrm{C}$ ), with alterations in the function of pro- and anticoagulant proteins, pro- and antifibrinolytics proteins, and platelets at progressively lower temperatures. $^{6-8}$ Accordingly, the temperature associated with DHCA is frequently among the usual suspects blamed for coagulopathy and the resultant postoperative bleeding.

\footnotetext{
From the a Division of Cardiovascular and Thoracic Surgery, Department of Surgery, UTMB-Galveston, Galveston; and ${ }^{\mathrm{b}}$ Division of Transfusion Medicine and Hemostasis, Department of Pathology, UT Southwestern, Dallas, Tex.

Disclosures: The authors reported no conflicts of interest.

The Journal policy requires editors and reviewers to disclose conflicts of interest and to decline handling or reviewing manuscripts for which they may have a conflict of interest. The editors and reviewers of this article have no conflicts of interest.

Received for publication March 12, 2021; revisions received March 12, 2021; accepted for publication March 15, 2021; available ahead of print March 18, 2021.

Address for reprints: Abe DeAnda, Jr, MD, Division of Cardiovascular and Thoracic Surgery, UTMB-Galveston, 301 University Blvd, Galveston, TX 77551 (E-mail: abdeanda@utmb.edu).

J Thorac Cardiovasc Surg 2023;165:552-3

$0022-5223 / \$ 36.00$

Copyright (c) 2021 by The American Association for Thoracic Surgery

https://doi.org/10.1016/j.jtcvs.2021.03.047
}

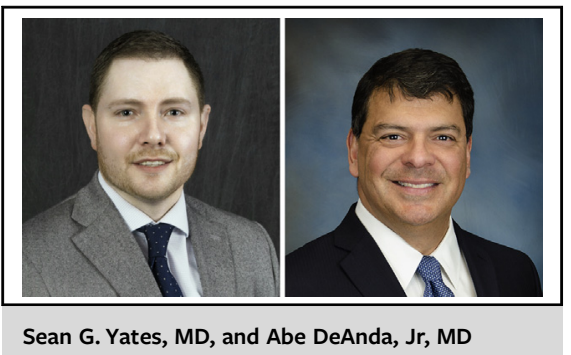

CENTRAL MESSAGE

Transfusion following aortic sur-

gery using hypothermia is asso-

ciated with negative outcomes.

Adjuncts to avoid transfusion

should include rewarming the

patient.

However, hypothermia-associated coagulopathy is not irreversible, and the best goal-directed therapy aimed at correcting this coagulopathy begins with rewarming the patient to a normal core temperature rather than the transfusion of blood components. ${ }^{9,10}$

No universally accepted temperature to separate from cardiopulmonary bypass exists, with authors of a recent guideline cautioning against hyperthermia and acknowledging that they could not make temperature recommendations for separation due to a paucity of published evidence. ${ }^{11}$ Moreover, in a previous study, one of us (A.D.) considered that the nadir temperature achieved during DHCA is not what influences bleeding; rather, bleeding was associated with the proximity to normal body temperature reached at the time the patient left the operating room. ${ }^{12}$

While patient blood-management programs can work in association with even complex aortic surgeries, ${ }^{13}$ these initiatives' success should not rely solely on altering transfusion thresholds or addressing preoperative anemia; instead, they should also include aggressive measures to mitigate bleeding in the first place. Although this often entails an additional suture or the use of a prothrombotic mechanical or flowable adjunct intraoperatively, consideration should also be given to a device readily available in every cardiac operating room and is uniquely capable of rewarming the patient, as opposed to a cooling blanket or raising the ambient temperature-the cardiopulmonary bypass machine. Sultan and colleagues have reminded us that 
transfusion is a double-edge sword, and avoidance of the need for blood and blood products includes optimizing hemostasis. Warming the patient to normothermia should be part of the algorithm.

\section{References}

1. LaPar DJ, Hawkins RB, McMurry TL, Isbell JM, Rich JB, Speir AM, et al. Preoperative anemia versus blood transfusion: which is the culprit for worse outcomes in cardiac surgery? J Thorac Cardiovasc Surg. 2018;156:66-74.e2.

2. Koch CG, Li L, Duncan AI, Mihaljevic T, Loop FD, Starr NJ, et al. Transfusion in coronary artery bypass grafting is associated with reduced long-term survival. Ann Thorac Surg. 2006;81:1650-7.

3. Velasquez CA, Singh M, Bin Mahmoud SU, Brownstein AJ, Zafar MA, Saeyeldin A, et al. The effect of blood transfusion on outcomes in aortic surgery. Int J Angiol. 2017;26:135-45.

4. Engoren MC, Habib RH, Zacharias A, Schwann TA, Riordan CJ, Durham SJ. Effect of blood transfusion on long-term survival after cardiac operation. Ann Thorac Surg. 2002; 74:1180-6.

5. Sultan I, Bianco V, Aranda-Michel E, Kilic A, Serna-Gallegos D, Navid F, et al. The use of blood and blood products in aortic surgery is associated with adverse outcomes. J Thorac Cardiovasc Surg. 2023;165:544-51.e3.

6. Rohrer MJ, Natale AM. Effect of hypothermia on the coagulation cascade. Crit Care Med. 1992;20:1402-5.
7. Whelihan MF, Kiankhooy A, Brummel-Ziedins KE. Thrombin generation and fibrin clot formation under hypothermic conditions: an in vitro evaluation of tissue factor initiated whole blood coagulation. J Crit Care. 2014;29: 24-30.

8. Wallner B, Schenk B, Hermann M, Paal P, Falk M, Strapazzon G, et al. Hypothermia-associated coagulopathy: a comparison of viscoelastic monitoring, platelet function and real time live confocal microscopy at low blood temperatures, an in-vitro experimental study. Front Physiol. 2020;11:843.

9. Reed RL II, Johnson TD, Hudson JD, Fischer RP. The disparity between hypothermic coagulopathy and clotting studies. J Trauma. 1992;33:465-70.

10. Michelson AD, MacGregor H, Barnard MR, Kestin AS, Rohrer MJ, Valeri CR Reversible inhibition of human platelet activation by hypothermia in vivo and in vitro. Thromb Haemost. 1994;71:633-40.

11. Engelman R, Bailer RA, Likosky DS, Grigore A, Dickinson TA, ShoreLesserson L, et al. The Society of Thoracic Surgeons, the Society of Cardiovascular Anesthesiologists, and the American Society of Extracorporeal Technology: clinical practice guidelines for cardiopulmonary bypass - temperature management during cardiopulmonary bypass. Ann Thorac Surg. 2015;100: 748-57.

12. Stein LH, Rubinfeld G, Balsam LB, Ursomanno P, DeAnda A Jr. Too cold to clot? Does intraoperative hypothermia contribute to bleeding after aortic surgery? Aorta (Stamford). 2017;5:106-16.

13. Smith D, Grossi EA, Balsam LB, Ursomanno P, Rabinovich A, Galloway AC et al. The impact of a blood conservation program in complex aortic surgery. Aorta (Stamford). 2013;1:219-26. 